\title{
Impact of Operational Parameters on Bacterial Community in a Full-Scale Municipal Wastewater Treatment Plant
}

\author{
AGNIESZKA CYDZIK-KWIATKOWSKA*, MAGDALENA ZIELIŃSKA and IRENA WOJNOWSKA-BARYŁA
}

University of Warmia and Mazury in Olsztyn, Department of Environmental Biotechnology

Received 16 June 2011, revised 12 December 2011, accepted 14 December 2011

\author{
Abstract
}

\begin{abstract}
A bacterial community in activated sludge from a full-scale municipal wastewater treatment plant was monitored throughout the year with the use of FISH, RISA and DGGE techniques. In the investigated range of temperatures $\left(11.9-21.6^{\circ} \mathrm{C}\right)$, a rise in temperature resulted in a lower total bacteria richness, while organic load rate changes from 0.09 to $0.21 \mathrm{~g} \mathrm{COD} \cdot \mathrm{g} \mathrm{TSS}^{-1} \cdot \mathrm{d}^{-1}$ were positively correlated with the number of bands in RISA patterns. The most diverse pattern (29 different bands) was characteristic for the activated sludge sample collected at the end of January at wastewater temperature of $11.9^{\circ} \mathrm{C}$. The ammonia-oxidising bacteria community did not change during the study, and comprised of 4 different bacterial populations with one dominant species closely related to Nitrosospira sp. REGAU (GenBank accession number AY635572.1). The percentage of ammonia-oxidising bacteria in the activated sludge varied from 6.2 to $19.5 \%$ and depended on temperature $(\mathrm{R}=0.61, \mathrm{p}=0.02)$ and organic load rate $(\mathrm{R}=-0.55, \mathrm{p}=0.04)$.
\end{abstract}

Ke y words: ammonia-oxidising bacteria, DGGE, FISH, molecular analysis of activated sludge, RISA

\section{Introduction}

One of the significant aspects of microbial community investigations is the evaluation of the impact of environmental conditions on bacterial consortia. In engineered systems, e.g. wastewater treatment plants there is a possibility to manipulate the technological parameters of the process and as a result to influence the microbial communities involved in removal of pollutants. It has recently been suggested that the diversity of specific bacterial groups in activated sludge influences the functioning of the reactor (Daims et al., 2001). The presence of many microorganisms able to conduct a specific process increases the probability that a change of environmental conditions does not worsen the effectiveness of wastewater treatment, since one of the species will adapt and maintain the specific metabolic pathway (LaPara et al., 2002). Taking this into consideration, the operational parameters of the wastewater treatment plant should be selected to favour the development of a highly diversified bacterial community.

Ammonia-oxidising bacteria (AOB) are of universal importance in activated sludge community since ammonia oxidation is the limiting step for nitrogen removal from wastewater. The growth rate of $A O B$ is slow and their population activity may be affected by operational/environmental factors e.g. solids retention time, ammonium and organic carbon concentration in the influent, pH or temperature (Nogueira et al., 2002; Avrahami et al., 2003; Kuo et al., 2006). Research by Siripong and Rittmann (2007) showed that monitoring of changes in the nitrifiers community can assist plant operators in preventing nitrification failure and the washing out of these bacteria from the system. It is therefore important to evaluate an impact of the operational parameters of the wastewater treatment process on $\mathrm{AOB}$ community in activated sludge.

The use of molecular techniques allows an insight to be gained into changes in bacterial communities in activated sludge in relation to environmental conditions. Much recent research focuses on investigating bacteria involved in wastewater pollutants removal (Onuki et al., 2000; Ariesyady et al., 2007; Zhao et al., 2008) but information about the relation between bacteria diversity and operating parameters is still limited. Juretschko et al. (2002) showed that consortia of microorganisms are influenced by wastewater composition and that diversity of bacteria is higher in systems treating municipal wastewater in comparison to industrial sewage treatment plants. Rowan et al. (2003) revealed that the bacterial diversity is linked to the type of bioreactor. The research indicated a higher diversity of

\footnotetext{
* Corresponding author: A. Cydzik-Kwiatkowska; Słoneczna 45G, 10-709 Olsztyn, Poland; phone: +48 895234185; fax: +48 985234131; e-mail: agnieszka.cydzik@uwm.edu.pl
} 
AOB in the trickling filter than in the biological aerated filter (BAF), and that the performance of the trickling filter was better than the BAF. Cydzik-Kwiatkowska and Wojnowska-Baryła (2008) proved that a higher AOB diversity was observed when only carbonates were present in the wastewater in comparison to conditions in which sodium acetate was introduced to the reactors and that a lower ammonia nitrogen load favoured a more diverse AOB community.

In the present study we focused on determining the impact of technological parameters on ammoniaoxidising and total bacteria community in activated sludge from a full-scale municipal wastewater treatment plant operating in temperate climate. In our research we combined fluorescent in situ hybridisation (FISH), Denaturing Gradient Gel Electrophoresis (DGGE), Ribosomal Intergenic Spacer Analysis (RISA) and DNA sequencing in order to obtain comprehensive results.

\section{Experimental}

\section{Materials and Methods}

Description of wastewater treatment plant. A oneyear study was conducted on a full-scale activated sludge wastewater treatment plant (WWTP) located in Poland (temperate climate). The WWTP treats on average $30,000 \mathrm{~m}^{3}$ of municipal wastewater per day and discharges it to the Eyna River. The treatment unit of the plant involves grates, grit chambers, primary clarifiers, an anaerobic chamber, predenitrification chamber, aeration chambers for simultaneous nitrification and denitrification $\left(16,380 \mathrm{~m}^{3}\right)$, and secondary clarifiers.

Activated sludge sampling. 14 activated sludge samples were collected at different dates from the WWTP. Three samples were collected in autumn: 1 - 14.10.2005, 2 - 8.11.2005, and 3 - 5.12.2005, three in winter: 4 - 03.01.2006, 5 - 31.01.2006, and 6 - 27.02.2006, four in spring: 7 - 27.03.2006, 8 - 24.04.2006, 9 - 10.05.2006, and $10-01.06 .2006$, and four in summer: $11-27.06 .2006,12-26.07 .2006$, 13 - 4.09.2006, $14-20.09 .2006$. Samples were collected directly from the aeration tank, transported on ice to the laboratory $(<30 \mathrm{~min})$ and processed immediately.
Analytical methods. Complete operating results were delivered by the WWTP laboratory, which monitors the activated sludge process daily. Analyses were performed according to Polish Standards (www.pkn. pl). Computations of technological parameters such as sludge retention time (SRT) or nitrogen use for biomass synthesis were performed as described in Metcalf and Eddy (1991).

Molecular analyses of activated sludge samples. Genomic DNA was isolated in duplicate from $400 \mathrm{mg}$ of centrifuged sludge sample using FastDNA ${ }^{\circledR}$ SPIN $^{\circledR}$ Kit (Q-BIOgene), according to the manufacturer's protocol. Quality and quantity of isolated DNA was measured spectrophotometrically using Biophotometer (Eppendorf). The DNA extracted from a sample was mixed and frozen at $-20^{\circ} \mathrm{C}$ for further analyses.

All PCR reactions were performed in Eppendorf Mastercycler Gradient (Eppendorf). The bacterial RIS (Ribosomal Intergenic Spacer) was amplified with primers 1 and 2 (Table I). Amplified fragments contained RIS plus approximately $380 \mathrm{bp}$ corresponding to flanking regions of genes coding for $16 \mathrm{~S}$ and $23 \mathrm{~S}$ rRNA. The PCR mixture contained $50 \mathrm{ng}$ of extracted total DNA, $0.5 \mu \mathrm{M}$ of each primer, $100 \mu \mathrm{M}$ of deoxynucleoside triphosphate mixture (Promega), $1.5 \mathrm{U}$ of GoTaq ${ }^{\circledast}$ DNA Polymerase (Promega), $6 \mu \mathrm{l}$ of reaction buffer supplied with polymerase, $1.5 \mathrm{mM} \mathrm{MgCl}_{2}$ and sterile water to a final volume of $30 \mu \mathrm{l}$. The PCR amplification was carried out using the following program: $95^{\circ} \mathrm{C}$ for $5 \mathrm{~min}, 35$ cycles of denaturation at $94^{\circ} \mathrm{C}$ for $30 \mathrm{~s}$, annealing at $43^{\circ} \mathrm{C}$ for $45 \mathrm{~s}$, extension at $72^{\circ} \mathrm{C}$ for $1 \mathrm{~min}$, and a final elongation at $72^{\circ} \mathrm{C}$ for $5 \mathrm{~min}$. The presence of PCR products was confirmed by analysing $5 \mu \mathrm{l}$ of the product on a $0.8 \%$ agarose gel stained with ethidium bromide.

After successful DNA amplification, $5 \mu$ of PCR products were applied to $6 \%$ polyacrylamide gel (29:1 acrylamide:bisacrylamide). Electrophoresis was carried out at $60 \mathrm{~V}$ in $1 \mathrm{x}$ TBE buffer $(89 \mathrm{mM}$ Tris base, $89 \mathrm{mM}$ boric acid, $2 \mathrm{mM}$ EDTA; $\mathrm{pH}$ 8.0). In order to avoid overlapping of bands and fully exploit the microbial diversity, each sample was electrophoresed for 60 , 120 and $180 \mathrm{~min}$ and all photos obtained were used for further analysis. After electrophoresis, the gel was

Table I

PCR primers used in the study

\begin{tabular}{|l|l|c|c|l|}
\hline \multicolumn{1}{|c|}{ Primer } & \multicolumn{1}{|c|}{ Sequence (5'-3') } & $\begin{array}{c}\text { Annealing } \\
\text { temperature }\end{array}$ & $\begin{array}{c}\text { Target } \\
\text { sequence }\end{array}$ & \multicolumn{1}{c|}{ Source } \\
\hline $\begin{array}{l}\text { amo } A-2 R \\
\text { amoA- } 1 F\end{array}$ & $\begin{array}{l}\text { ccc ctc tgc aaa gcc ttc ttc } \\
\text { att cta ctg gtg gt }\end{array}$ & $60^{\circ} \mathrm{C}$ & $a m o A$ & $\begin{array}{l}\text { Rotthauwe } \text { et al. (1997) } \\
\text { (modified by Nicolaisen and Ramsing, 2002) }\end{array}$ \\
\hline 1 & $\begin{array}{l}\text { ttg tac aca ccg ccc gtc a } \\
\text { gt act tag atg tt cag ttc }\end{array}$ & $43^{\circ} \mathrm{C}$ & $R I S$ & Dolzani et al. (1995) \\
\hline
\end{tabular}

a - cgc cgc gcg gcg ggc ggg gcg ggg gcg ggg 
Table II

Probes used for hybridisation

\begin{tabular}{|c|c|c|c|l|}
\hline Probe & Sequence (5'-3') & Label & \% formamide & \multicolumn{1}{c|}{ Specificity } \\
\hline EUB338 & GCTGCCTCCCGTAGGAGT & FITC & 20 & Eubacteria \\
\hline Nso190 & CGATCCCCTGCTTTTCTCC & Cy3 & 55 & $\begin{array}{l}\text { Majority of AOB: Nitrosomonas, Nitrosococcus, Nitrosolobus, } \\
\text { Nitrosovibrio, Nitrosospira }\end{array}$ \\
\hline
\end{tabular}

stained with SYBRgold (Molecular Probes) at 10,000x dilutions in 1x TBE buffer for $30 \mathrm{~min}$, viewed with an ultraviolet transilluminator and recorded with CCD camera (Gel Logic 200, Eastman Kodak Company). Bands were detected automatically from digital images of the gel using KODAK 1D 3.6 Image Analysis Software (Eastman Kodak Company). The size of PCR products was estimated using $100 \mathrm{bp}$ O'GeneRuler ladder (Fermentas).

Amplification of amoA gene fragment for DGGE was performed as in RIS reactions, except for applied primers and annealing temperature (Table I). DGGE electrophoresis was performed with a D-CODE Universal Mutation System (Bio-Rad). The PCR samples were applied to $8 \%$ polyacrylamide gel (37.5:1 acrylamide:bisacrylamide) in a $0.5 \times$ TAE buffer $(40 \mathrm{mM}$ Tris, $40 \mathrm{mM}$ acetic acid, $1 \mathrm{mM}$ EDTA; $\mathrm{pH}$ 7.5) with a denaturing gradient ranging from 30 to $70 \%$. Denaturation of $100 \%$ corresponded to $7 \mathrm{M}$ urea and $40 \%$ formamide. Electrophoresis was run at a constant voltage of $80 \mathrm{~V}$ at $60^{\circ} \mathrm{C}$. After electrophoresis, the gel was processed as described above. The most intense band was cut from the gel, reamplified using specific primers (amoA-1F with no GC clamp) and sequenced by a specialist laboratory (www.oligo.ibb.waw.pl). The nucleotide sequence was compared with sequences in the GenBank using the BLASTn program (Altschul et al., 1997) and deposited in the GenBank under accession no. GU073249).

The biomass used for FISH analysis was fixed according to Amann et al. (1990). The prepared sample was vortexed and kept at $4^{\circ} \mathrm{C}$ for 1 day. After centrifugation ( $3 \mathrm{~min}, 4,000 \mathrm{rpm}$ ), the supernatant was removed and the sample was resuspended in a mixture of $1 x$ PBS and $96 \%$ ethanol (volume ratio of mixture components $1: 1)$ and stored at a temperature of $-20^{\circ} \mathrm{C}$. For analysis, $10 \mu \mathrm{l}$ of sample was spread on each well of the glass slides (Marienfeld Laboratory Glassware), dried for about $10 \mathrm{~min}$ at $46^{\circ} \mathrm{C}$, and dehydrated by serial immersions of the slide in 50, 80, and $96 \%(\mathrm{v} / \mathrm{v})$ ethanol (3 min each). The composition of the hybridisation buffer was the following: $180 \mu \mathrm{l}$ of $5 \mathrm{M} \mathrm{NaCl}, 20 \mu \mathrm{l}$ of $1 \mathrm{M}$ TrisHCl $(\mathrm{pH} 8.0), 550 \mu \mathrm{l}$ of formamide, $250 \mu \mathrm{l}$ of ultra clean water and $2 \mu \mathrm{l}$ of $10 \%(\mathrm{w} / \mathrm{v})$ SDS. The washing buffer, containing $100 \mu$ of $5 \mathrm{M} \mathrm{NaCl}, 1000 \mu \mathrm{l}$ of $1 \mathrm{M}$ TrisHCl ( $\mathrm{pH} 8.0), 500 \mu \mathrm{l}$ of $0,5 \mathrm{M}$ EDTA $(\mathrm{pH} 8.0), 50 \mu \mathrm{l}$ of $10 \%(\mathrm{w} / \mathrm{v})$ SDS, and distilled water to complete the buffer to $50 \mathrm{ml}$, was preheated in a water bath to $48^{\circ} \mathrm{C}$. Two molecular probes, as proposed by Mobarry et al. (1996) were used for hybridisation (Table II). In order to detect Eubacteria, only one molecular probe EUB338 was used (Chae et al., 2008) that would make it simpler to utilize the FISH method in wastewater treatment plants.

A mixture of $140 \mu \mathrm{l}$ of hybridisation buffer and molecular probes $(10 \mathrm{pmol} / \mu \mathrm{l})$ was prepared and placed in each well. The slide was transferred into the hybridisation chamber and incubated at $46^{\circ} \mathrm{C}$ for $3 \mathrm{~h}$. After hybridisation the slide was incubated in the washing buffer for $10 \mathrm{~min}$ in a preheated water bath at $48^{\circ} \mathrm{C}$. The slide was rinsed with cold distilled water and dried. Slides were mounted in VectaShield (Vector Laboratories) embedding medium. Epifluorescence microscopy by Nikon Eclipse (Nikon, 100x objective) was used for examination. For a reproducible and statistically correct result, 30 images for each probe taken from 30 different positions of the slide were analysed (Hall et al., 2003).

The area covered by specific probe Nso190 and the area covered by the EUB338 probe in the same field of the slide glass, taken as images, were calculated by using ImageJ software (National Institutes of Health, USA). The occupation ratio of the area given by Nso190 to the area from EUB338 gives a direct measurement of the number of active ammonia-oxidising bacteria (Rittmann et al., 1999).

Statistical analysis. The relationships between bacterial richness and chemical parameters in the effluent of the treatment facility were determined by correlation analyses using the STATISTICA 7.0 programme (StatSoft, USA). The strength of the correlation was evaluated according to Stanisz (2000). Analyses were carried out at a confidence interval of $95 \%$. In the text, after \pm the standard deviation is given. On the basis of RISA patterns, distance matrix analyses were performed according to the method of Nei Li (Nei and Li, 1979), using the DGGEstat 1.0 programme (van Hannen, the Netherlands Institute for Ecological Research, NIOO-KNAW, the Netherlands). Binary sequences were generated by determining the number and position of bands in individual lanes compared to all of the band positions detected in all of the lanes. The samples were clustered using the unweighted pair group method of arithmetic averages (UPGMA), bootstrapping was conducted with 1000 replicates. 


\section{Results and Discussion}

In a temperate climate one of the major factors influencing biological wastewater treatment efficiency is temperature. In this study the temperature of wastewater fluctuated considerably throughout the year. The maximum temperature amplitude of wastewater during the study period was $9.7^{\circ} \mathrm{C}$ (Fig. 1a).

The operating data for the facility are presented in Table III. On the base of organic $\left(B_{C}\right)$ and nitrogen $\left(B_{N}\right)$ load rates it can be concluded that the plant represented a system with a low load rate. The average concentration of organic compounds expressed as COD in the influent was $416.1 \pm 66.1 \mathrm{mg} \mathrm{COD} / \mathrm{l}$, while in the effluent during the year it averaged $37.0 \pm 5.1 \mathrm{mg} \mathrm{COD} / 1$ (Fig. 1b). COD removal maintained at the level of $90.8 \pm 2.5 \%$. The average concentration of total nitrogen (TN) in the influent was $62.1 \pm 8.9 \mathrm{mg} \mathrm{N} / \mathrm{l}$. The highest TN concentration in the effluent of 20.8 and $16.1 \mathrm{mg}$ $\mathrm{N} / \mathrm{l}$ was observed at the turn of winter and spring (Fig. 1c). During the rest of the year this value did not exceed $13 \mathrm{mg} \mathrm{N} / \mathrm{l}$. A high percentage of total nitrogen removal $(84.1 \pm 6.4 \%)$ provided evidence of nitrification. It was calculated that $6.4 \pm 2.9 \mathrm{mg} \mathrm{N} / \mathrm{l}$ was used for biomass synthesis. Regarding phosphorus concentration, in the influent it averaged $10.6 \pm 3.0 \mathrm{mg} \mathrm{P} / \mathrm{l}$, while in the effluent it was in the range of $0.3-1.7 \mathrm{mg}$ $\mathrm{P} / \mathrm{l}$, except the sample for January, when the concentration of phosphorus increased to $4.1 \mathrm{mg} \mathrm{P} / 1$ (Fig. 1d). The average efficiency of phosphorus removal in the system was $89.4 \pm 8.9 \%$.

An identification of microorganisms involved in pollutants removal gives us some information about properties of activated sludge, however, the complexity of factors influencing activated sludge in WWTP results in extremely variable microbial structure that is unlikely to occur in another WWTP. It is therefore more important to reveal general dependences between the microbial community as a whole and technological parameters of the process. In our research the bacterial

Table III

Summary wastewater treatment plant operating data during the study period.

\begin{tabular}{|l|c|}
\hline \multicolumn{1}{|c|}{ Parameter } & $\begin{array}{c}\text { Mean value } \\
\pm \text { standard deviation }\end{array}$ \\
\hline Sludge volume index $(\mathrm{ml} / \mathrm{g})$ & $260.0 \pm 77.0$ \\
\hline Total suspended solids $(\mathrm{mg} \mathrm{TSS} / \mathrm{l})$ & $5229.0 \pm 1117.2$ \\
\hline Organic loading $\left(\mathrm{g} \mathrm{COD} \cdot \mathrm{g} \mathrm{TSS}^{-1} \cdot \mathrm{d}^{-1}\right)$ & $0.15 \pm 0.03$ \\
\hline Nitrogen loading $(\mathrm{g} \mathrm{N} \cdot \mathrm{g} \mathrm{TSS}$ & -1 \\
$\left.\cdot \mathrm{d}^{-1}\right)$ & $0.02 \pm 0.005$ \\
\hline COD/TKN $(\mathrm{g} \mathrm{COD} / \mathrm{g} \mathrm{N})$ & $6.8 \pm 1.3$ \\
\hline Sludge yield $(\mathrm{g} \mathrm{TSS} / \mathrm{g} \mathrm{COD})$ & $0.3 \pm 0.1$ \\
\hline HRT $(\mathrm{h})$ & 13.0 \\
\hline SRT $(\mathrm{d})$ & $21.6 \pm 14.9$ \\
\hline
\end{tabular}
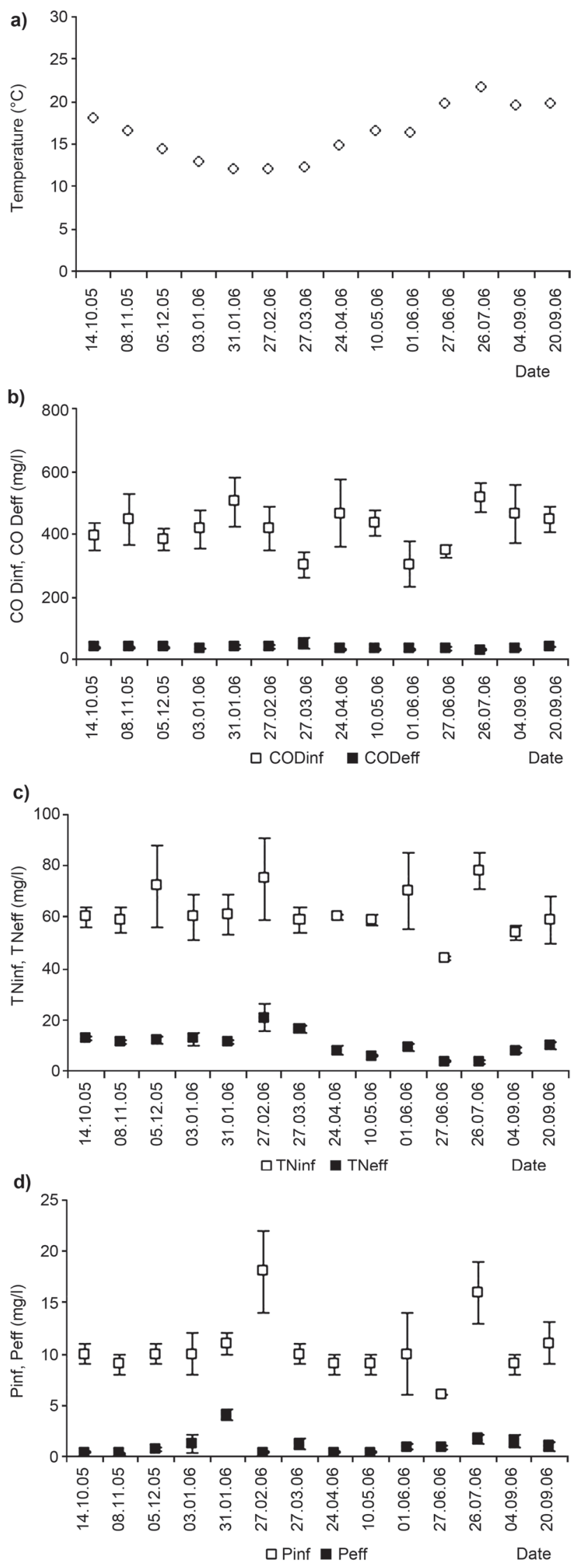

Fig. 1. Temperature (a) and influent $\left({ }_{\text {inf }}\right)$ and effluent $\left({ }_{\text {eff }}\right)$ quality of wastewater: COD (b), total nitrogen (c), phosphorus (d).

Each point is the mean of 4 measurements, vertical bars indicate standard deviation. 

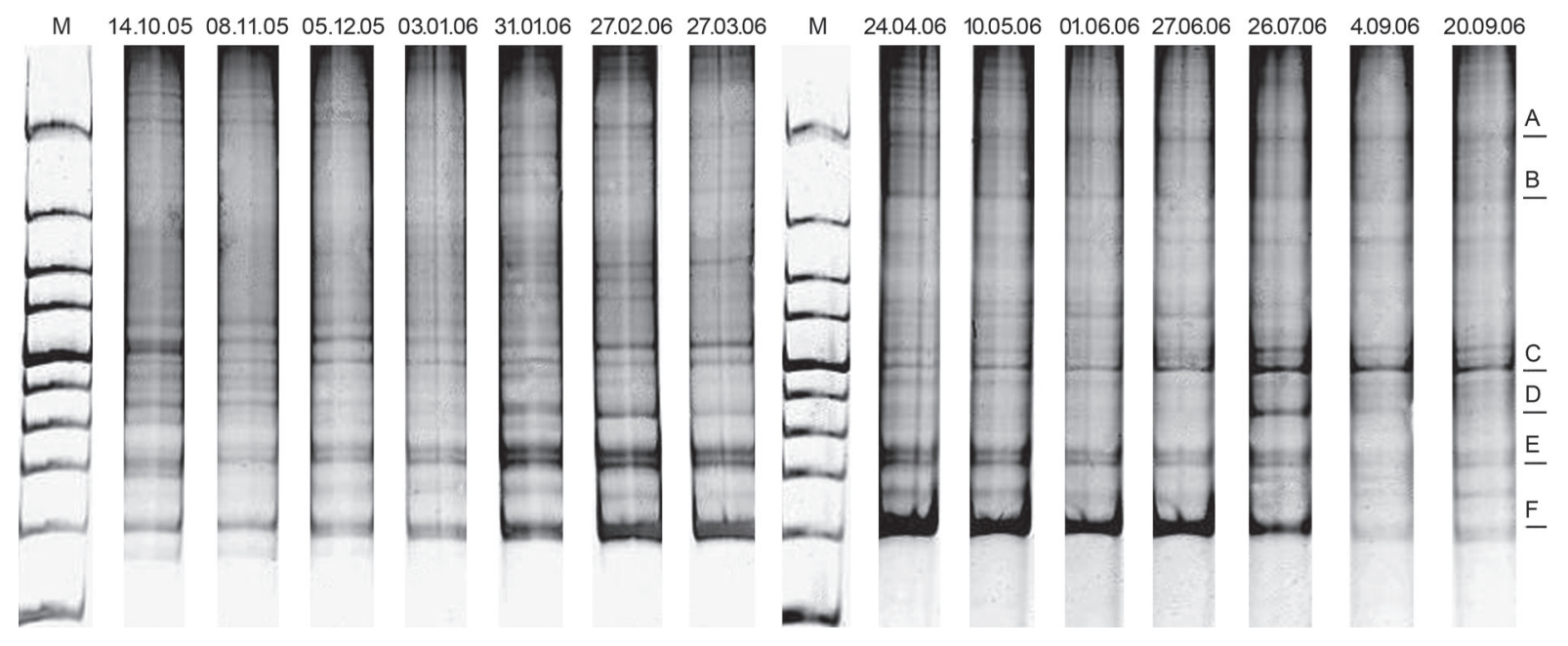

Fig. 2. RISA fingerprints of bacterial community from activated sludge.

Lanes are labelled with the dates of sampling.

Exemplary bands are marked with capital letters, $\mathrm{M}$ - molecular weight marker $100 \mathrm{~kb}$ O'GeneRuler (Fermentas).

community changed moderately throughout the year while the effluent quality remained relatively stable. The RISA fingerprints were complex, and the mean number of bands per lane was $22.1 \pm 4.2$ (Fig. 2). Several bands were present only temporarily (e.g. bands labelled B and D), while some bands were detectable throughout the whole year, though their intensity varied sometimes with time (e.g. bands A, C, E, F). The intensity of band $\mathrm{F}$ was significantly higher during the period from March to June, suggesting that this species was present in the highest number in spring. It is probable that the bands detected in all the samples are the crucial bacterial populations for activated sludge performance. The richness of bacterial consortia expressed by the number of different bands in the RISA pattern fluctuated during the year (Fig. 3). The most diverse patterns were characteristic for activated sludge samples collected at the end of the winter and at the beginning of the spring. The highest number of bands (29) was noted in the sample collected 31.01.2006.

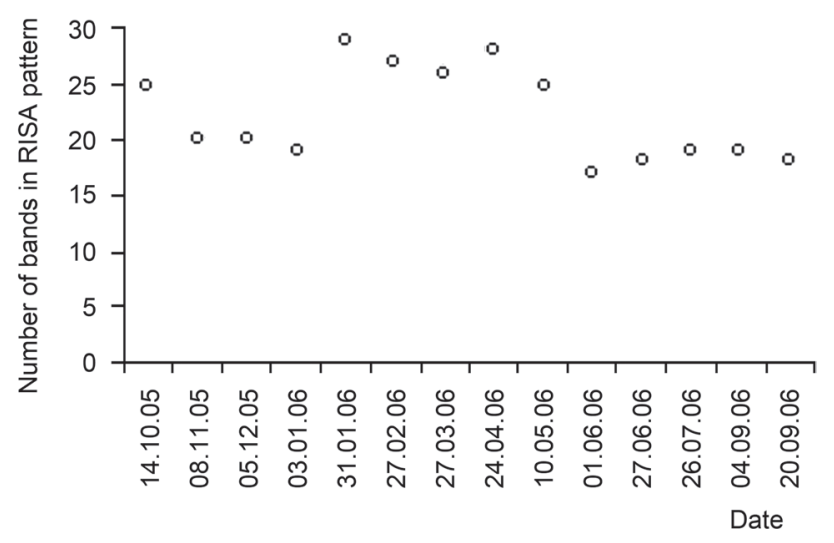

Fig. 3. The number of bands in RISA patterns obtained for activated sludge samples collected at given dates.

Grey vertical lines separate samples from different seasons of the year.
The higher temperature of wastewater leads to an increase in the population density and metabolic activity, and shortens the generation time of bacteria in activated sludge (Saleem et al., 2003). Our research showed that a statistically significant correlation occurred between bacterial richness of sample and the temperature of wastewater (Fig. 4a). The value of Pearson's correlation $\operatorname{rank}(\mathrm{R}=-0.61)$ indicates that the negative correlation between the analysed parameters was strong. Moreover, richness of microorganisms was correlated with organic load rate $\left(\mathrm{B}_{\mathrm{C}}\right)$ of the system (Fig. $4 \mathrm{~b}$ ). During the year of sampling $B_{C}$ varied from 0.09 to $0.21 \mathrm{~g}$ $\mathrm{COD} \cdot \mathrm{g} \mathrm{TSS}^{-1} \cdot \mathrm{d}^{-1}$ and bacteria richness increased with increasing $\mathrm{B}_{\mathrm{C}}$. Similar results were obtained by Xia et al. (2008). Authors investigated the microbial community structure response to different ratios of carbon to nitrogen $(\mathrm{C} / \mathrm{N}$ 3:1, 5:1, 10:1) in wastewater in a suspended carrier biofilm reactor with simultaneous nitrification and denitrification. On the basis of DGGE and FISH analyses it was shown that total diversity of microbial community structure increased with increasing organic carbon concentration in wastewater. It is worth noting that the correlation obtained in our study is probably true only in a limited range of organic load rate. At a very high $B_{C}$, the diversity tends to decrease because a large quantity of organic carbon in wastewater stimulates dynamically growing bacteria with a very short generation time and these compete out other species and dominate the bacterial population.

Cluster analysis of RISA fingerprints revealed that the bacterial community changed gradually with the passage of time (Fig. 5). Three distinct branches were formed in the dendrogram. The first four samples formed the first branch, the following five the second branch which was connected to the third branch clasping the last five samples. The bootstrap values for the 

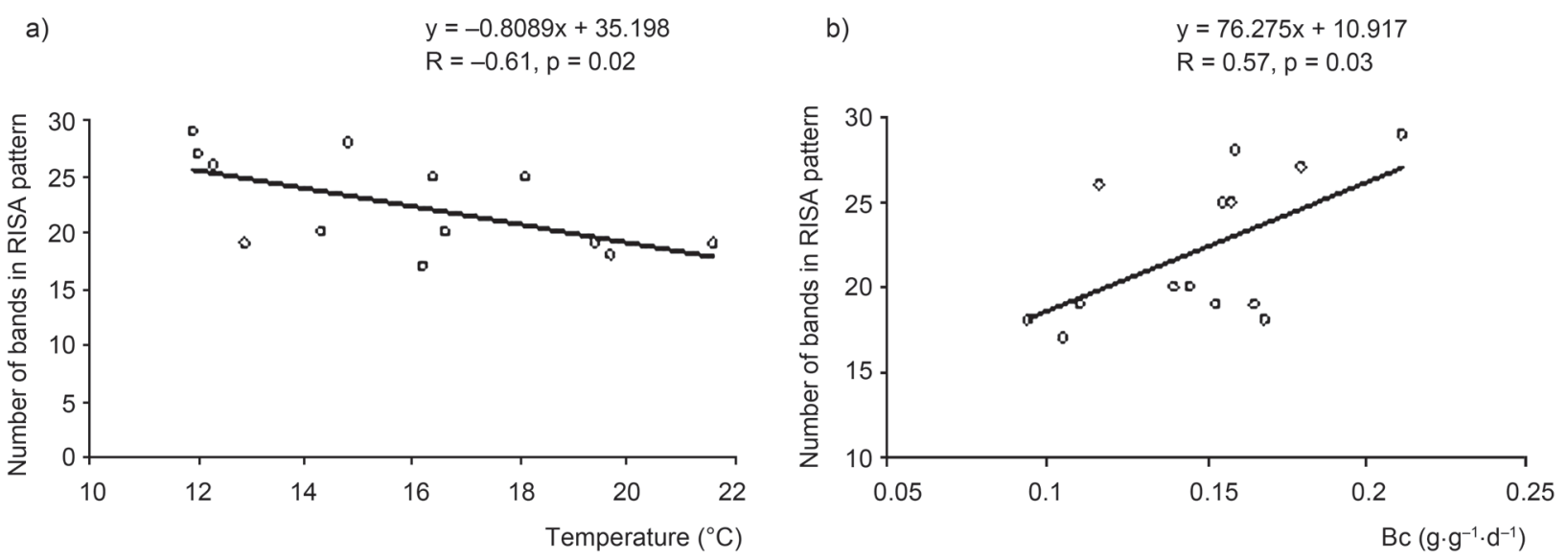

Fig. 4. Relationship between the number of bands in RISA pattern and a) wastewater temperature, b) organic load rate during the study

third branch was 90.7 , suggesting that summer bacterial communities were the most similar to each other, and differed significantly from consortia developed in other seasons of the year. LaPara and Ghosh (2006) noted a similar situation in research carried out in a fullscale municipal wastewater treatment facility. DGGE fingerprints obtained on the basis of activated sludge samples from $25^{\text {th }}$ June to $3^{\text {rd }}$ September formed a distinct branch in the dendrogram.

DGGE of PCR-amplified amoA gene fragments revealed that there were 4 different $\mathrm{AOB}$ populations

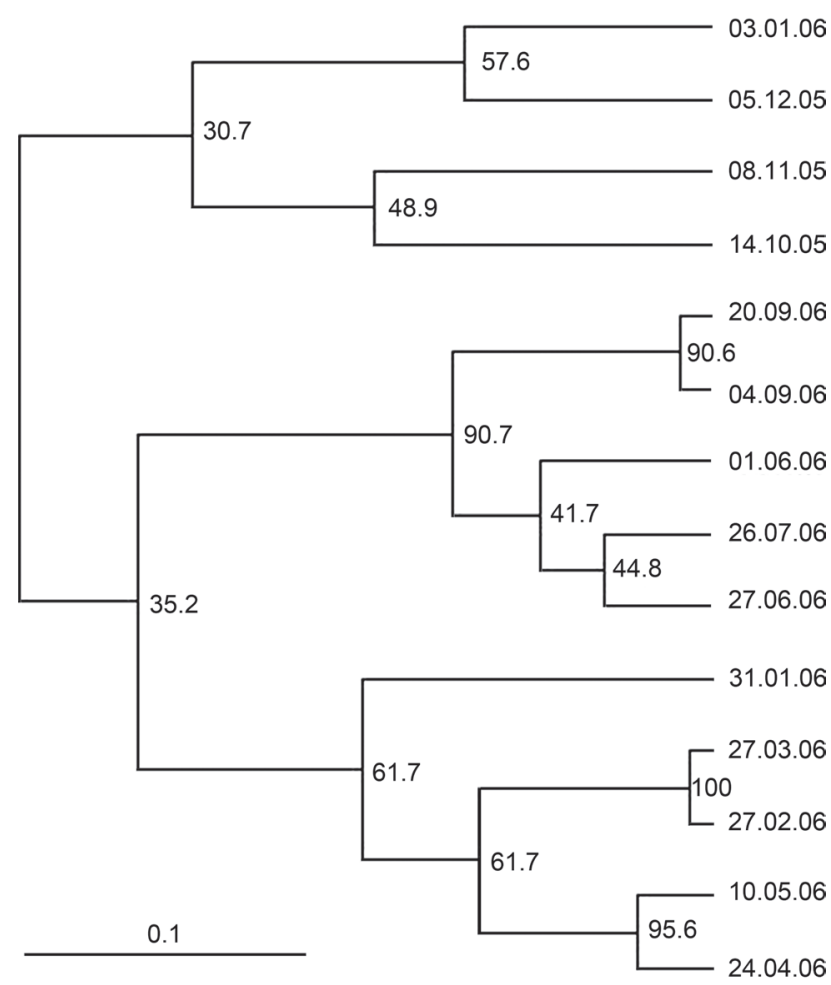

Fig. 5. Dendrogram revealing the relatedness of RISA fingerprints of the bacterial community from aeration tank of investigated wastewater treatment plant.

Branches are labelled with the dates of sampling; bootstrap values for branches are given at the nodes. per sample, and that the ammonia-oxidising bacteria community did not change throughout the study (data not shown). The coexistence of various nitrifiers with different growth and survival characteristics may be valuable for maintaining the stability and performance of nitrifying bioreactors. Sequencing of the dominant band indicated that the partial amoA gene sequence was similar ( $89 \%$ similarity) to the sequence of ammonia monooxygenase from Nitrosospira sp. REGAU (GenBank accession number AY635572.1). LaPara and Ghosh (2006) investigated the AOB community in a full-scale municipal wastewater treatment facility using the nested PCR-DGGE technique. The fingerprint obtained was also dominated by one band. This band was, however, not phylogenetically related to any known AOB. Siripong and Rittman (2007), using the T-RFLP technique, examined the impact of temperature, sludge age, input of industrial wastewater and other technological parameters on the diversity of nitrifiers in seven water reclamation plants in two different seasons (winter and summer). Authors have shown that only the seasonal temperature variations changed the nitrifying community, in particular the balance between Nitrosospira and Nitrosomonas, however, both Nitrosospira and Nitrosomonas coexisted in winter and summer samples. Authors' conclusion is that a combination of low temperature and high SRT may favour Nitrosospira. Limpiyakorn et al. (2006) investigated AOB communities in 12 full-scale sewage activated sludge systems in three different seasons using PCR-DGGE-cloning-sequencing of $16 \mathrm{~S}$ rRNA genes. However, in this case in all samples one of the identified sequence types of the Nitrosomonas oligotropha cluster was the dominant AOB in every system and every season studied.

FISH analyses revealed that the percentage of ammonia-oxidising bacteria in activated sludge decreased from 19.5 to $14.2 \%$ in autumn (Fig. 6), and to $6.2-9.7 \%$ in winter. In spring, the percentage of $\mathrm{AOB}$ increased to $14.9 \%$ and remained at a similar level until the end 


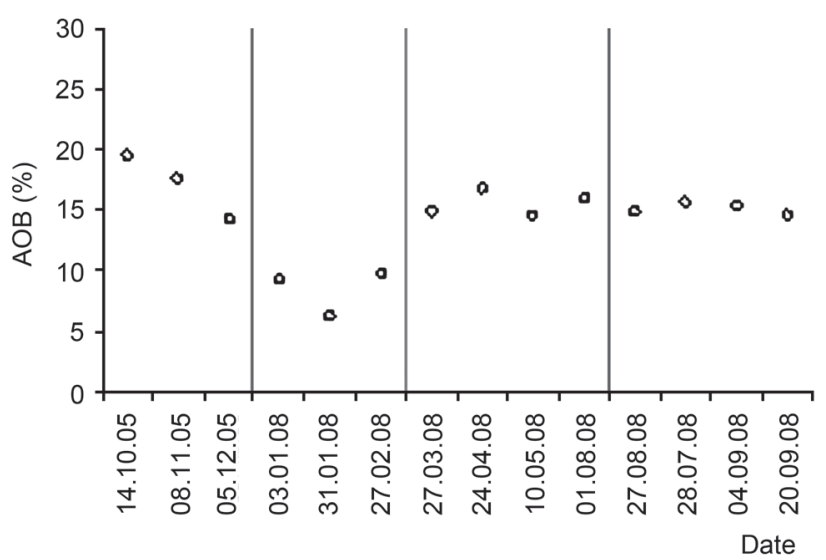

Fig. 6. Percentage of AOB in activated sludge samples collected at given dates.

Grey vertical lines separate samples from different seasons of the year.

of summer. The values obtained are consistent with the observations of Okabe et al. (1999) who reported that ammonia-oxidising bacteria comprise from 5 to $20 \%$ of bacteria in domestic wastewater systems. We showed that there was a significant correlation $(\mathrm{R}=0.61, \mathrm{p}=0.02)$ between the wastewater temperature and percentage of $\mathrm{AOB}$ in activated sludge (Fig. 7a). The temperature dropped below $12^{\circ} \mathrm{C}$ in February which caused a decrease in $\mathrm{AOB}$ participation in the activated sludge to $6.2 \%$. Low temperatures generally have a drastic effect on bacterial process rates and this is especially important when nitrification processes are concerned: below $15^{\circ} \mathrm{C}$, the nitrification rate drops sharply, and is reduced by $50 \%$ at $12^{\circ} \mathrm{C}$ (Focht and Verstraete, 1977). However, Rittmann and Snoeyink (1984) mentioned that nitrification processes have the potential to achieve a good ammonia removal even at low temperatures. The critical aspect seems to be the maintenance of slow-growing nitrifying bacteria in the system. In our research, SRT applied at the level of $21.6 \pm 14.9 \mathrm{~d}$ guaranteed that these essential bacteria would not be washed out from the wastewater treatment plant.

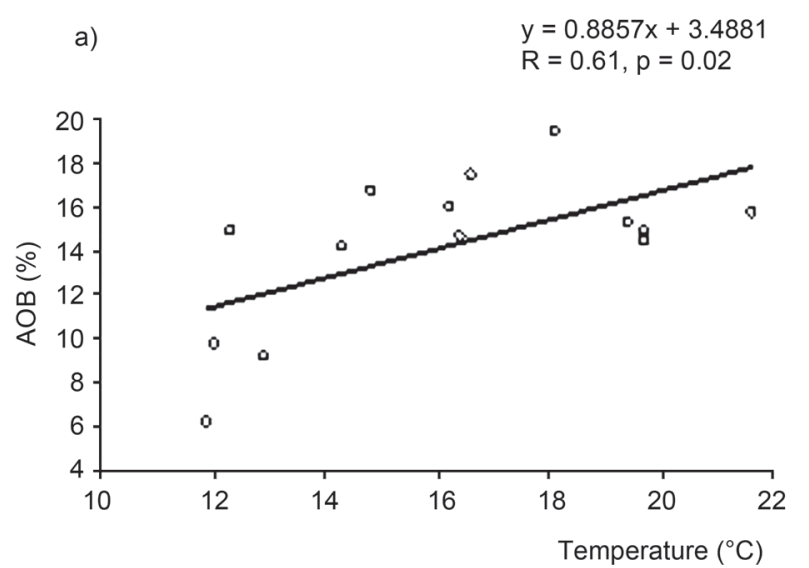

Throughout all the seasons studied the activated sludge process showed evidence of stable nitrification with efficiency at the level of 73.3-91.4\%. No relationship between nitrification efficiency and ammoniaoxidising bacteria contribution in activated sludge ( $\mathrm{R}=0.06, \mathrm{p}=0.83$ ) was noted. This result is not consistent with previous studies conducted in full-scale nitrifying trickling filters, suggesting that the concentration of AOB has an impact on effluent quality (Dionisi et al., 2002). In the research of Ebie et al. (2002), the FISH method with $16 \mathrm{~S}$ rRNA-targeted oligonucleotide probes was used for quantitative estimation of ammoniaoxidising bacteria in an anaerobic-aerobic activated sludge process with membrane filtration. At the beginning of the experiment, the occupation ratio of $\mathrm{AOB}$ increased as nitrification progressed. Later, similarly to our results, the occupation ratio decreased, but good nitrification ability was, however, preserved.

The fact that organic carbon influences AOB populations in wastewater treatment systems is discussed in the literature (Lazarova et al., 1998; Nogueira et al., 2002). Organic carbon compounds in wastewater stimulate heterotrophic bacteria which compete for oxygen with nitrifiers and may produce intermediary metabolic byproducts, which inhibit AOB (Gieseke et al., 2001). Xia et al. (2008) showed that the population of nitrifiers was inversely proportional to the $\mathrm{C} / \mathrm{N}$ ratio in wastewater with an average fraction of $\mathrm{AOB}$ and nitrite-oxidising bacteria (NOB) to all bacteria of 5.4, $4.8,3.1 \%$ and $4.6,3.5,2.7 \%$, respectively, as the $\mathrm{C} / \mathrm{N}$ ratio changed from 3:1, 5:1 to 10:1. Our research was conducted in a full-scale municipal wastewater treatment plant with a low organic load rate at a level of

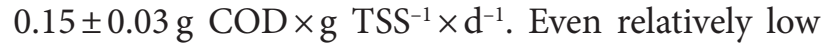
organic load rate, however, influenced the $\mathrm{AOB}$ population in activated sludge (Fig. $7 \mathrm{~b} ; \mathrm{R}=-0.55, \mathrm{p}=0.04$ ). In practice, the organic load rate in a wastewater treatment plant can be easily adjusted. On the basis of our research it may be concluded that the negative impact

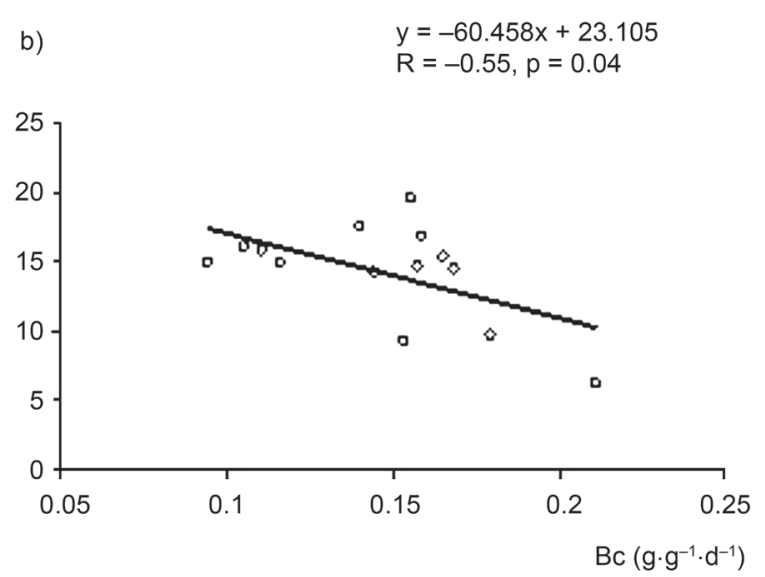

Fig. 7. Relationship between the participation of $A O B$ in activated sludge and a) wastewater temperature, b) organic load rate 
of low temperatures on $\mathrm{AOB}$ participation in activated sludge can be minimized by lowering the $\mathrm{B}_{\mathrm{C}}$ value.

Conclusions. Presented research possesses utilitary values. It allows observing general trends in microorganisms' consortia during the year of plant operation in temperate climate, and characterizing the bacterial community, especially $\mathrm{AOB}$, in activated sludge, in correlation with operational parameters of a full scale WWTP. The following conclusions may be drawn from the research:

1. The total bacterial community in activated sludge changed moderately with the passage of time. Bacterial communities from summer samples were the most similar to each other and differed significantly from consortia developed in other parts of the year.

2. In investigated range of values the total bacteria richness was correlated with the two parameters of wastewater treatment process that is the temperature $(\mathrm{R}=-0.61, \mathrm{p}=0.02)$ and organic load rate $(\mathrm{R}=0.57$, $\mathrm{p}=0.03)$.

3. The percentage of $\mathrm{AOB}$ in activated sludge varied from 6.2 to $19.5 \%$ during the year of study and depended on temperature $(\mathrm{R}=0.61, \mathrm{p}=0.02)$ and organic load rate $(\mathrm{R}=-0.55, \mathrm{p}=0.04)$.

4. The AOB community comprised of 4 different bacterial populations and did not change during the investigation period, with one dominant species closely related to Nitrosospira sp. REGAU.

\section{Acknowledgements}

The authors are grateful to WWTP staff for providing the samples and data from the activated sludge system.

\section{Literature}

Altschul S.F., T.L. Madden, A.A. Schaffer, J. Zhang, Z. Zhang, W. Miller and D.J. Lipman. 1997. Gapped BLAST and PSI-BLAST: A new generation of protein database search programs. Nucleic Acids Res. 25: 3389-3402.

Amann R.I., L. Krumholz and D.A. Stahl. 1990. Fluorescentoligonucleotide probing of whole cells for determinative, phylogenetic, and environmental studies in microbiology. J. Bacteriol. 172: 762-770.

Ariesyady H.D., T. Ito and S. Okabe. 2007. Functional bacterial and archaeal community structures of major trophic groups in a full-scale anaerobic sludge digester. Water Res. 41: 1554-1568.

Avrahami S., W. Liesack and R. Conrad. 2003. Effects of temperature and fertilizer on activity and community structure of soil ammonia oxidizers. Environ. Microbiol. 5: 691-705.

Chae K.J., T. Rameshwar, A. Jang, S.H. Kim and I.S. Kim. 2008. Analysis of the nitrifying bacterial community in BioCube sponge media using fluorescent in situ hybridization (FISH) and microelectrodes. J. Environ. Manage. 88: 1426-1435.

Cydzik-Kwiatkowska A. and I. Wojnowska-Baryła. 2008. The impact of organic carbon and ammonia load in wastewater on ammonia-oxidizing bacteria community in activated sludge. Pol. J. Microbiol. 57(3): 241-248.
Daims H., U. Purkhold, L. Bjerrum, E. Arnold, P.A. Wilderer and M. Wagner. 2001. Nitrification in sequencing biofilm batch reactors: lessons from molecular approaches. Water Sci. Technol. 43: 9-18. Dionisi H.M., A.C. Layton, G. Harms, I.R. Gregory, K.G. Robinson and G.S. Sayler. 2002. Quantification of Nitrosomonas oligotropha-like ammonia-oxidizing bacteria and Nitrospira spp. from full-scale wastewater treatment plants by competitive PCR. Appl. Environ. Microbiol. 68: 245-253.

Dolzani L., E. Tonin, C. Lagatolla, L. Prandin and C. MontiBragadin. 1995. Identification of Acinetobacter isolates in the A. calcoaceticus-A. baumannii complex by restriction analysis of the 16S-23S rRNA intergenic-spacer sequences. J. Clin. Microbiol. 33: 1108-1113.

Ebie Y., M. Matsumura, N. Noda, S. Tsuneda, A. Hirata and Y. Inamori. 2002. Community analysis of nitrifying bacteria in an advanced and compact Gappei-Johkasou by FISH and PCR-DGGE. Water Sci. Technol. 46: 105-111.

Focht D.D. and W. Verstraete. 1977. Biochemical ecology of nitrification and denitrification. Adv. Microb. Ecol. 1: 135-214.

Gieseke A., U. Purkhold, M. Wagner, R. Amann and A. Schramm. 2001. Community structure and activity dynamics of nitrifying bacteria in a phosphate-removing biofilm. Appl. Environ. Microbiol. 67: 1351-1362.

Hall S.J., J. Keller and L.L. Blackall. 2003. Microbial quantification in activated sludge: the hits and misses. Water Sci. Technol. 48: 121-126.

Juretschko S., A. Lo, A. Lehner and M. Wagner. 2002. The microbial community composition of a nitrifying-denitrifying activated sludge from an industrial sewage treatment plant analyzed by the full-cycle 16S rRNA approach. Syst. Appl. Microbiol. 25: 84-99.

Kuo D.H.W., K.G. Robinson, A.C. Layton, A.J. Meyers and G.S. Sayler. 2006. Real-time PCR quantification of ammonia-oxidizing bacteria (AOB): solids retention time (SRT) impacts during activated sludge treatment of industrial wastewater. Environ. Eng. Sci. 23(3): 507-520.

LaPara T.M., C.H. Nakatsu, L.M. Pantea and J.E. Alleman. 2002. Stability of the bacterial communities supported by a seven-stage biological process treating pharmaceutical wastewater as revealed by PCR-DGGE. Water Res. 36: 638-646.

LaPara T.M. and S. Ghosh. 2006. Population dynamics of the ammonia-oxidizing bacteria in a full-scale municipal wastewater treatment facility. Environ. Eng. Sci. 23: 309-319.

Lazarova V., D. Bellahcen, D. Rybacki, B. Rittmann and J. Manem. 1998. Population dynamics and biofilm composition in a new threephase circulation bed reactor. Water Sci. Tech. 37: 149-158.

Limpiyakorn T., F. Kurisu and O. Yagi. 2006. Quantification of ammonia-oxidizing bacteria populations in full-scale sewage activated sludge systems and assessment of system variables affecting their performance. Water Sci. Technol. 54: 91-99.

Metcalf and Eddy Inc. 1991. Design of Facilities for the Biological Teratment of Wastewater, pp: 529-662. In: Tchobanoglous G. and F.L. Burton (eds.), Wastewater Engineering: Treatment, Disposal and Reuse, $3^{\text {rd }}$ ed., McGraw Hill Inc.

Mobarry B.K., M. Wagner, V. Urbain, B.E. Rittmann and D.A. Stahl. 1996. Phylogenetic probes for analyzing abundance and spatial organization of nitrifying bacteria. Appl. Environ. Microbiol. 62: 2156-2162.

Nei M. and W.H. Li. 1979. Mathematical model for studying genetic variation on terms of restriction endonucleases. Proceedings of the National Academy of Sciences 76, USA, pp. 5269.

Nicolaisen M.H. and N.B. Ramsing. 2002. Denaturing gradient gel electrophoresis (DGGE) approaches to study the diversity of ammonia-oxidizing bacteria. J. Microbiol. Meth. 50: 189-203.

Nogueira R., L.F. Melo, U. Purkhold, S. Wuertz and M. Wagner. 2002. Nitrifying and heterotrophic population dynamics in biofilm 
reactors: effects of hydraulic retention time and the presence of organic carbon. Water Res. 36: 469-481.

Okabe S., H. Satoh and Y. Watanabe. 1999. In situ analysis of nitrifying biofilms as determined by in situ hybridization and the use of microelectrodes. Appl. Environ. Microbiol. 65: 3182-3191.

Onuki M., H. Satoh, T. Mino and T. Matsuo. 2000. Application of molecular methods to microbial community analysis of activated sludge. Water Sci. Tech. 42: 17-22.

Rittmann E. and V.L. Snoeyink. 1984. Achieving biologically stable drinking water. J. Am. Water Works Ass. 76: 106-114.

Rittmann B.E., C.S. Laspidou, J. Flax, D.A. Stahl, V. Urbain, H. Harduin, J.J. van der Waarde, B. Geurkink, M.J.C. Henssen, H. Brouwer and others. 1999. Molecular and modeling analyses of the structure and function of nitrifying activated sludge. Water Sci. Technol. 39: 51-59.

Rotthauwe J.-H., K.-P. Witzel and W. Liesack. 1997. The ammonia monooxygenase structural gene $a m o A$ as a functional marker: molecular fine scale analysis of natural ammonia-oxidizing populations. Appl. Environ. Microbiol. 63: 4704- 4712.

Rowan A.K., J.R. Snape, D. Fearnside, M.R. Barer, T.P. Curtis and I.M. Head. 2003. Composition and diversity of ammonia-oxidizing bacterial communities in wastewater treatment reactors of different design treating identical wastewater. FEMS Microbiol. Ecol. 43: 195-206.

Saleem M., A.A. Bukhari and M.H. Al-Malack. 2003. Seasonal variations in the bacterial population in an activated sludge system. J. Environ. Eng. Sci. 2: 155-162.

S. Siripong and B.E. Rittmann. 2007. Diversity study of nitrifying bacteria in full-scale municipal wastewater treatment plants. Water Res. 41: 1110-1120.

Stanisz A. 2000. Bases of statistics for science. Ch. 21: Analisis of correlation (in Polish). Med. Praktyczna 10: 176-181.

Xia S., J. Li and R. Wang. 2008. Nitrogen removal performance and microbial community structure dynamics response to carbonnitrogen ratio in a compact suspended carrier biofilm reactor. Ecol. Eng. 32: 256-262.

Zhao Y., A. Wang, N. Ren and Y. Zhao. 2008. Microbial community structure in different wastewater treatment processes characterized by single-strand conformation polymorphism (SSCP) technique. Front. Environ. Sci. Eng. China 2: 116-121.

Internet sources: www.oligo.ibb.waw.pl www.pkn.pl 